\title{
Study on Web-Site Attributes and Predatory Efficiency of Dark Tetragnathid Spider in Point Calimere Wildlife and Bird Sanctuary
}

\section{Samidurai Jayakumar ${ }^{1}$, Joothi Paramanandham ${ }^{\star 2}$, Veerapan Duraimurugan ${ }^{3}$, Ambalavanan Sankari ${ }^{4}$, Arunagiri Ramya ${ }^{5}$, Selvaraj Sathiskumar ${ }^{6}$ and Amirthalingam Durga ${ }^{7}$}

\author{
P.G. and Research Department of Zoology and Wildlife Biology, A.V.C. College (Autonomous), \\ Mannampandal, Mayiladuthurai - 609305. Tamil Nadu, India. \\ 1 jayakumar.msv@gmail.com; ${ }^{2 *}$ paramusacon2010@gmail.com; ${ }^{3}$ duraimuruganv@hotmail.com; \\ ${ }^{4}$ sankarizoology@gmail.com; ${ }^{5}$ aramya1610@gmail.com; ${ }^{6}$ ksathish605@gmail.com; \\ ${ }^{7}$ durgabsc1998@gmail.com
}

Keywords: Dark tetragnathid spider, Point Calimere Wildlife and Bird Sanctuary, web attributes, web architecture, prey and predatory potential

\begin{abstract}
Spiders represent one of the most abundant components of the predatory arthropods in terrestrial ecosystem. Their effectiveness at restricting pest populations, both alone and as part of natural enemy complex has well demonstrated in many countries. The web, web-site attributes and predatory efficiency of Dark Tetragnathid Spider Tetragnatha mandibulata were assessed in Point Calimere Wildlife and Bird Sanctuary between August 2015 and March 2016. In the present study, the spiders used limited number of plants species. The relationship between web architecture and web-site attributes was estimated using Pearson's correlation. Number of spiders recorded in the web showed the positive correlation with web horizontal and vertical length of the capture areas $(\mathrm{p}<0.05)$. Similarly, the web circumference showed the positive interaction with plant height and canopy width $(p<0.05)$, which clearly indicated the importance of vegetations across the webs of Dark Tetragnathid Spider. Further, the microhabitat selection and utilization could also be impacted by non-trophic factors like structural features of plants that provide architectural supports to spiders. A total of 4620 insect pests comprising seven orders were entangled by the webs of dark tetragnathid spiders. Number of spiders in the web were positively correlated with number of insect pests $(p<0.05)$, which clearly explained that the Dark Tetragnathid spiders restricting pest populations and therefore they are considered as useful organism in biological control.
\end{abstract}

\section{Introduction}

Spiders are one of the most familiar and fascinating creatures of the natural world [1] and they are considered as predators in terrestrial ecosystems and found in diverse habitats like crop fields, thick forest floors, human habitations, deserted buildings, under stones and logs [2-5]. Spiders are one of the most successful groups of animals based on their web architecture, which very often used to capture the prey species. Their effectiveness at restricting pest populations has been reported in many countries [6-8]. Spiders also have a very diverse range of life styles and foraging behaviors $[9,10]$. Based on the foraging strategies, they are categorized into many guilds and classified into web-building and hunting groups. The hunting spiders are grouped into foliage runners, ground runners, stalkers and ambushers. The web building spiders are grouped into sheet-web builders, wandering sheet/tangle-weavers, orb-weavers, and 3-D space-web weavers [1].

The spiders create special attention to the naturalist because of their unique weaving capability to construct their webs with geometrical precision and beauty. Spider webs are in various shapes and sizes with the design of the web depending on the ecology of species [2]. The size and web characteristic spiders are important predictors of the size and type of prey the spider will capture [11] along with their capture efficiency [12-16]. Several factors reported to affect an orbweb-weavers ability to intercept prey, including insect availability [12, 17], web area [14], web orientation [16] and web locations [18]. Prokop and Gryglakova [14] reported that web design 
including mesh height, capture thread length, and web area were affected by web height in wasplike spiders Argiope bruennichi (Araneae). Based on the types and patterns of webs, the spiders are classified up to family level and sometimes even up to genus and species levels. Dark Tetragnathid Spider Tetragnatha mandibulata is an nocturnal spiders spin largely orb webs at sundown among grasses and other foliage, usually beside a stream or tank and some time they also construct communal sheath web based on the availability of microhabitats [3]. In addition, the spiders' webs trap more number of insect pests using sticky threads. From the foregoing account, it is clear that the studies of web design and web- site characteristics/attributes are important in order to understand the bio-control role of spiders in environment. Hence, the present study was aimed to document the web, web-site attributes and the predatory potential of Dark Tetragnathid Spider in Point Calimere Wildlife and Bird Sanctuary in Tamil Nadu.

\section{Materials and Methods}

\section{Study Area}

The present investigation was conducted in a portion of at Point Calimere Wildlife and Bird Sanctuary (PCWBS), located along the Palk Strait in three districts of Tamil Nadu: Nagapattinam, Tiruvarur and Thanjavur. It lies in between $79.399 \mathrm{E} \& 79.884 \mathrm{E}$ longitudes and $10.276 \mathrm{E} \&$ $10.826 \mathrm{~N}$ latitudes, covering an area of 38,500 hectares from Point Calimere in the east to Adirampattinam in the west. The Ramsar Site comprises of Point Calimere Sanctuary, Panchanadikulam Wetland, Thalainayar Reserved Forest and Muthupet Mangroves. Except the Thalainayar Reserved Forest, the remaining constituents are parts of the Great Vedaranyam Swamp. Bio-geographically, the Ramsar Site is a mix of salt swamps, mangroves, backwaters, mudflats, grasslands and Tropical Dry Evergreen Forest. It has recorded the largest congregation of migratory waterbirds in the country with a peak population exceeding 1,00,000. The sanctuary is also home to the largest population of the endemic Blackbuck (Antilope cervicapra) in South India. The general geological formation of these area is plain and coastal, the Cauvery and its offshoots are the principal rivers. Fisheries and agriculture are the primary activities of this area.

\section{Web count and morphometric measurement}

A random observation was made to know the range of active webs accommodated on a plant species. Direct observation method was adopted to assess the number of spiders and prey in the web. Quantification of insect prey was investigated in three ways viz., (i) prey entangled in the web, (ii) wrapped package found in the web and (iii) dead prey's external skeleton in the web. The collected insects and their body parts were used to identify the prey species (only up to order). Identification of spider and prey species was done using standard manuals [35; 36]. A total of 20 selected webs were carefully examined in the field to check its compositions including number of spiders and prey species, number of egg pouches. The morphometric measurements of horizontal and vertical length of the capture area were collected. Similarly, web-site attributes, namely plant height, canopy width, web height from the ground, web distance from the cultivable regions, human activities, water bodies and the availability of artificial light sources were also recorded. All the measurements were made using 50 meter fiberglass measuring tape (Model: Freemans).

\section{Statistical Analysis}

Kruskal Wallis test was carried to examine significance in variation of selected web and website characteristics of spider species. The probability level determining significant differences was $\mathrm{p}<0.05$ for all statistical tests. Pearson's Correlation Coefficient was carried out to test the relationship among web attributes and prey predatory association. All these calculations were performed using statistical software, SPSS version 16.0. 


\section{Results}

\section{Web and web-site attributes of Dark Tetragnathid Spiders}

The Dark Tetragnathid Spiders constructed their communal webs either on Suaeda monica or Acacia nilotica. Between the plant species, Suaeda monica had the highest number of webs (90\%) than Acacia nilotica. Web and web-site characters of Dark Tetragnathid Spiders recorded are shown in table 1. The entire web was divided in to two regions, namely horizontal length of the capture area and the vertical length of the capture area, used as a tool to trap the insect pests. The horizontal length of the capture area ranged from 5.0 to 30.0 feet and the vertical length of the capture area ranged between 3.0 and 15.0 feet. The circumference of the web was in the range of 8.0 to 76.0 feet.

Table 1. Web and web-site attributes of Dark Tetragnathid Spiders.

\begin{tabular}{|c|c|c|c|c|}
\hline S. No & Attributes (feet) & Average \pm SE & Minimum & Maximum \\
\hline \multicolumn{5}{|c|}{ Web characters } \\
\hline 1 & Horizontal length of the capture area & $9.25 \pm 1.52$ & 5.0 & 30.0 \\
\hline 2 & Vertical length of the capture area & $6.80 \pm 0.69$ & 3.0 & 15.0 \\
\hline 3 & Web Circumference & $28.3 \pm 4.57$ & 8.0 & 76.0 \\
\hline \multicolumn{5}{|c|}{ Web-site Characters } \\
\hline 4 & Plant height & $4.15 \pm 0.55$ & 2.0 & 10.0 \\
\hline 6 & Canopy width & $6.80 \pm 0.69$ & 3.0 & 15.0 \\
\hline 7 & Web height from ground & $3.90 \pm 1.65$ & 1.0 & 3.4 \\
\hline 8 & Web distance from water bodies & $20.0 \pm 0.00$ & 20 & 20 \\
\hline
\end{tabular}

Web-site attributes of spiders were also observed. The height and canopy width of plant species preferred by spiders were in the range of 2.0 to 10.0 and 3.0 to 15.0 feet respectively. The web height from ground ranged from 1.0 to 3.4 feet. Most of the Tetragnathid spiders found build their webs far away from the cultivable regions, human activity, and artificial light source. Nevertheless, they constructed their webs much closer to the water bodies (Table 1). Web attributes, namely horizontal length of the capture area and vertical length of the capture area did not vary significantly between the plant species $(\mathrm{p}>0.05)$. However, the web of Dark Tetragnathid Spiders recorded on Acacia nilotica had the highest horizontal and vertical length of the capture area, height and canopy width than the webs recorded from Suaeda monoica (Table 2).

Table 2. Web and web-site attributes (Mean \pm SE) of Dark Tetragnathid Spiders based on the plant species.

\begin{tabular}{|c|c|c|c|c|c|}
\hline \multirow[t]{2}{*}{ S. No. } & \multirow[t]{2}{*}{ Attributes (feet) } & \multirow{2}{*}{$\begin{array}{c}\text { Acacia } \\
\text { nilotica } \\
(\mathrm{N}=2)\end{array}$} & \multirow{2}{*}{$\begin{array}{c}\text { Suaeda } \\
\text { monoica } \\
(\mathrm{N}=18)\end{array}$} & \multicolumn{2}{|c|}{$\begin{array}{c}\text { Kruskal Wallis } \\
\text { test }\end{array}$} \\
\hline & & & & $\mathbf{F}$ & p value \\
\hline \multicolumn{6}{|c|}{ Web characters } \\
\hline 1 & Horizontal length of capture area & $17.5 \pm 9.5$ & $8.33 \pm 1.34$ & 3.7 & $>0.05$ \\
\hline 2 & Vertical length of capture area & $9 \pm 1$ & $6.55 \pm 0.74$ & 1.1 & $>0.05$ \\
\hline 3 & Web Circumference & $54 \pm 17$ & $25.44 \pm 4.39$ & 4.0 & $>0.05$ \\
\hline \multicolumn{6}{|c|}{ Web-site characters } \\
\hline 4 & Plant height & $5 \pm 0$ & $4.05 \pm 0.62$ & 0.2 & $>0.05$ \\
\hline 5 & Web height from ground & $1 \pm 0$ & $4.22 \pm 1.83$ & 0.3 & $>0.05$ \\
\hline 6 & No. of egg pouches & $914 \pm 526$ & $535.7 \pm 141.2$ & 0.6 & $>0.05$ \\
\hline
\end{tabular}




\section{Relationship between web and web-site attributes of Dark tetragnathid Spiders}

To understand the relationship between web architecture and web-site attributes of Dark Tetragnathid Spiders, the correlation matrix was computed and shown in table 3. The number of spiders in the webs had the positive correlation with web horizontal length of the capture area $(\mathrm{r}=0.664 ; \mathrm{p}<0.05)$, vertical length of the capture area $(\mathrm{r}=0.771 ; \mathrm{p}<0.05)$, web circumference $(r=0.823 ; p<0.05)$, plant height $(r=0.654 ; p<0.05)$ and canopy width $(r=0.771 ; p<0.05)$ of the plant species. When the number of spiders increases, the capture area of web also increases. Similarly, when the plant height increases, the pole height and canopy width of the plant species also increases.

The web horizontal length of the capture area showed positive correlation with web vertical length of the capture area $(\mathrm{r}=0.522 ; \mathrm{P}>0.05)$, web circumference $(\mathrm{r}=0.860 ; \mathrm{P}<0.05)$, plant height $(\mathrm{r}=0.455 ; \mathrm{P}<0.05)$ and canopy width of the plant species $(\mathrm{r}=0.522 ; \mathrm{P}>0.05)$. Similarly, the web vertical length of the capture area had the positive correlation with web circumference $(\mathrm{r}=0.752$; $\mathrm{P}<0.05)$ and plant height $(\mathrm{r}=0.789 ; \mathrm{P}<0.05)$. The canopy width of plant species utilized by Dark Tetragnathid Spider had the highest positive correlation with web vertical length of the capture area $(\mathrm{r}=1.00 ; \mathrm{P}<0.05)$ (Table 3). The web circumference of Dark Tetragnathid Spiders showed the positive correlation with plant height $(\mathrm{r}=0.662 ; \mathrm{P}<0.05)$ and plant canopy width $(\mathrm{r}=0.752 ; \mathrm{P}<0.05)$. Similarly, the plant height had the positive correlation with canopy width of the plant species $(\mathrm{r}=0.789 ; \mathrm{P}<0.05)$.

Table 3. Correlation matrix shows the relationship between web and web-site attributes of Dark Tetragnathid Spider.

\begin{tabular}{|c|c|c|c|c|c|c|}
\hline \multicolumn{2}{|c|}{$\begin{array}{l}\text { Web and web-site } \\
\text { attributes (feet) }\end{array}$} & \multirow{2}{*}{$\begin{array}{c}\begin{array}{c}\text { Horizontal } \\
\text { length of } \\
\text { capture } \\
\text { area }\end{array} \\
0.664^{* *}\end{array}$} & \multirow{2}{*}{$\begin{array}{c}\begin{array}{c}\text { Vertical } \\
\text { length of } \\
\text { capture } \\
\text { area }\end{array} \\
0.771^{* *}\end{array}$} & \multirow{2}{*}{$\begin{array}{c}\begin{array}{c}\text { Web } \\
\text { circumference }\end{array} \\
0.823^{* *}\end{array}$} & \multirow{2}{*}{$\begin{array}{c}\begin{array}{c}\text { Plant } \\
\text { height }\end{array} \\
0.654^{* *}\end{array}$} & \multirow{2}{*}{$\begin{array}{c}\begin{array}{c}\text { Canopy } \\
\text { width }\end{array} \\
0.771^{* *}\end{array}$} \\
\hline \multirow{2}{*}{ No. of Spider } & r value & & & & & \\
\hline & $p$ value & 0.001 & 0.000 & 0.000 & 0.002 & 0.000 \\
\hline \multirow{2}{*}{$\begin{array}{l}\text { Horizontal } \\
\text { length of } \\
\text { capture area }\end{array}$} & r value & & $0.522^{*}$ & $0.860^{* *}$ & $0.455^{*}$ & $0.522^{*}$ \\
\hline & $\mathrm{p}$ value & & 0.018 & 0.000 & 0.044 & 0.018 \\
\hline \multirow{2}{*}{$\begin{array}{l}\text { Vertical } \\
\text { length of } \\
\text { capture area }\end{array}$} & r value & & & $0.752^{* *}$ & $0.789^{* *}$ & $1.00^{* *}$ \\
\hline & $\mathrm{p}$ value & & & 0.000 & 0.000 & 0.000 \\
\hline \multirow{2}{*}{$\begin{array}{l}\text { Web } \\
\text { circumference }\end{array}$} & r value & & & & $0.662^{* *}$ & $0.752^{* *}$ \\
\hline & $\mathrm{p}$ value & & & & 0.001 & 0.000 \\
\hline \multirow{2}{*}{ Plant height } & r value & & & & & $0.789^{* *}$ \\
\hline & $\mathrm{p}$ value & & & & & 0.000 \\
\hline
\end{tabular}

**Correlation is significant at the 0.01 level (2-tailed)

*Correlation is significant at the 0.05 level (2-tailed)

\section{Predatory potential of Dark Tetragnathid Spiders}

In order to understand the predatory potential of Dark Tetragnathid Spiders, total number of spiders and total number of prey species (insects) were observed. Further, the insect species were identified and grouped as order for further analysis. Among the order, Odonata and Hymemoptera had the highest numbers of species (3 species) followed by Diptera and Lepidoptera with two species each. The remaining orders had only one species each (Table 4). A total of 4620 insects belonging to seven orders were observed in the webs. Among the orders, Diptera was the most 
frequently captured order with 4386 insects followed by the order Lepidoptera with 110 insects and order Hymenoptera with 91 insects, while the prey species belonging to order Araneae had the lowest number with 3 individuals.

To understand the relationship between spider and prey species, the correlation coefficient was performed and the results are given in table 5. The total number of spiders were positively correlated with three orders, namely Diptera $(r=0.946 ; n=20 \mathrm{P}<0.05)$, Lepidoptera $(\mathrm{r}=0.807$; $\mathrm{P}<0.05)$ and Coleoptera $(\mathrm{r}=0.450 ; \mathrm{P}<0.05)$, while, the orders, namely Orthoptera and Hymenoptera showed the negative correlation.

Table 4. Insect order captured by the webs of Dark tetragnathid Spiders.

\begin{tabular}{|c|l|c|c|}
\hline S. No. & Insect orders & $\begin{array}{c}\text { No. of insect } \\
\text { species Caught }\end{array}$ & $\begin{array}{c}\text { Total number } \\
\text { of insect caught }\end{array}$ \\
\hline $\mathbf{1}$ & Coleoptera & 1 & 4 \\
\hline $\mathbf{2}$ & Diptera & 2 & 4386 \\
\hline $\mathbf{3}$ & Hymenoptera & 3 & 91 \\
\hline $\mathbf{4}$ & Lepidoptera & 2 & 110 \\
\hline $\mathbf{5}$ & Odonata & 3 & 20 \\
\hline $\mathbf{6}$ & Orthoptera & 1 & 6 \\
\hline $\mathbf{7}$ & Araneae & 1 & 3 \\
\hline & Total & 13 & 4620 \\
\hline
\end{tabular}

Table 5. Relationship between spider and insect orders.

\begin{tabular}{|l|c|c|}
\hline \multirow{2}{*}{\multicolumn{1}{c|}{ Insect orders }} & \multicolumn{2}{c|}{ Dark Tetragnathid Spiders (n=20) } \\
\cline { 2 - 3 } & $\mathbf{r}$ & P value \\
\hline Odonata & 0.212 & 0.371 \\
\hline Hymenoptera & -0.09 & 0.706 \\
\hline Diptera & $.946^{* *}$ & 0.00 \\
\hline Lepidoptera & $.807^{* *}$ & 0.00 \\
\hline Araneae & -0.205 & 0.386 \\
\hline Coleoptera & $.450^{*}$ & 0.047 \\
\hline Orthoptera & -0.316 & 0.175 \\
\hline
\end{tabular}

*Correlation is significant at the 0.05 level (2-tailed).

**Correlation is significant at the 0.01 level (2-tailed).

\section{Discussion}

\section{Web and web-site attributes of spider species}

The architectural characteristics of a spider web often reflect its functionality and the behavioral processes of spiders [19]. The location of a spider web within its habitat often conveys important information about the behavior and ecology of the spiders [18]. According to Sebastian and Peter [3], the Dark Tetragnathid Spiders are nocturnal spiders spin large orb webs and sometime communal web at sundown among grasses and other foliage, usually beside a stream or tank. In the present study most of the Tetragnathid Spiders are constructed their communal webs 
closer to water bodies within 20 feet and the same is coincided with findings described above. Further, it is proved that that the Dark Tetragnathid Spiders are considered as habitat specialist and preferred either trees or shrubs for their web construction. For web-building spiders, prey capture consists of multiple, independent components and therefore the web must be placed and oriented in such a way to maximize the likelihood of intercepting a prey item [20]. The location and orientation of a web may have large impacts on the types of prey that can potentially be tapped. Spider webs that are built high above the ground and oriented vertically may intercept more flying prey species, while webs built low to the ground and oriented horizontally may intercept more epigeal prey species $[21,22]$. Similar to the above findings, the Dark Tetragnathid Spiders constructed their webs near to ground, which ultimately helped the spiders to capture more numbers of insects in the study area.

The amount, density and organization of the web's silk might influence several functional characteristics, including the likelihood and size of prey that can be caught $[23,24]$. Thus, the diverse combinations of web size, silk density and silk patterns could be observed across species, with a variety of functional roles for spiders that may target different types of prey and use different tactics to capture their prey [25]. Every aspect of web-building spiders is mediated through the web and characteristics of the site where the web is constructed. This microhabitat is a small unit of habitat in which the spiders have very intimate association. Foraging by web-building spiders consists of the utilization of specific microhabitats for the construction of webs [26, 27]. In the present observation, the number of spiders in the webs had the positive correlation with web horizontal length of the capture area, vertical length of the capture area, web circumference, plant height and canopy width of the plant species. When the number of spiders increases, the capture area of web also increases. Similarly, when the plant height increases, the pole height and canopy width of the plant species also increases. Further, the Dark Tetragnathid Spiders preferred only a limited number of plants species and the variation in web architecture and microhabitat selection by Dark Tetragnathid spiders indicate the intimate association between spiders and micro habitats as explained above.

\section{Predatory potential of spider species}

One of the most diverse and abundant types of natural enemy in agro-ecosystems worldwide are the web-building spiders [28]. They are generalist predators that construct silk webs to capture a variety of prey items, including pest and non-pest prey [29, 30]. Web-building spiders are a useful organism in biological control because they construct webs to trap prey renders several ecological roles [31]. The present study is also evidence that the Dark Tetragnathid Spiders are effectively trapping numerous prey species using their specially designed webs which exhibited the fact that they are useful organism in biological control as reported by several researchers $[29 ; 4 ; 30]$. In agroecosystems, web-building spiders can potentially contribute to the suppression of pest insects, such as aphids [29] and leafhoppers [32]. However, their contribution to pest control is determined by a variety of factors, including the availability of suitable microhabitats [33], the presence of competitors in the environment [32], and the availability and relative abundance of pest and nonpest prey [29, 32].

The present study clearly revealed that the Tetragnathid Spiders are effective bio-control agents by trapping wide verities of insect pests belong to the order Diptera, Lepidoptera, Hymenoptera. Diptera is one of the largest insect orders in the world and includes familiar insects such as mosquitoes, midges, sand flies, house flies and blowflies. Many species of Diptera are important due to the role they play in disease transmission. Similarly, the order Lepidoptera includes many dangerous moths considered as pests. As the spiders are consuming large number insect pests belonging to these orders, they can be considered as natural enemies. Further, the nature of the feeding of any animal depends on the nature of the food availability. The results of the present study clearly indicate that the number of spider is depends on the availability of number pests. Our findings support the hypothesis is that the prey population increases in the webs, the population of spiders also increases. According to Riechert and Bishop [34], the increase of spider's 
density could decrease the pest density and pest damage. Thus the spiders included in the present study serve as buffer in natural environment and limits the exponential growth of prey population in the study site.

\section{Conclusion}

The web, web-site attributes and predatory efficiency of Dark Tetragnathid Spider Tetragnatha mandibulata were assessed in Point Calimere Wildlife and Bird Sanctuary. The spiders used limited number of plants species and the relationship between web architecture and web-site attributes indicate the intimate association between spiders and micro habitats. The number of spiders recorded in the web showed the positive correlation with web horizontal and vertical length of the capture areas and the web circumference showed the positive interaction with plant height and canopy width, which clearly indicates the importance of plant species availability. The total number of spiders in the web was positively correlated with number of insect pests, which clearly concluded that the Dark Tetragnathid Spiders restricting pest populations and therefore they are considered as useful organism in biological control.

\section{Acknowledgment}

The authors wish to acknowledge Tamil Nadu Forest Department and A. V. C. College (Autonomous), Mannampandal, Mayiladuthurai for the support. We thank Mr. Rahul, Wildlife Warden, Nagapattinam Division, Tamil Nadu and Dr. S. Asokan, Principal, A.V.C. College (Autonomous) for their permission and support to conduct this survey as a part of Flamingo Festival 2016. We are also thankful to Mr. Naguraan, Bird watcher for his help in the field.

\section{References}

[1] A. Sankari, A comparative study on the ecology of spiders (Aranea) in the agricultural crop field, garden and paddy store-house in the Nagapattinam district, Tamil Nadu, South India, Dissertation, Bharathidasan University, India, 2011.

[2] B.K. Tikader, Handbook of Indian Spiders, Zoological Survey of India, Calcutta, India, 1987.

[3] P.A. Sebastian, K.V. Peter, Spiders of India, Universities Press, Hyderabad, India, 2009.

[4] S. Jayakumar, A. Sankari, Spider population and their predatory efficiency in different rice establishment techniques in Aduthurai, Tamil Nadu, Journal of Biopesticides. 3(1) (2010) 20 27.

[5] A. Sankari, K. Thiyagesan, Spider (Araneae) density and diversity in relation to crop stages in the paddy fields of Nagapattiam District, Tamil Nadu, India, Scientific Transactions in Environment Technovation. 5(4) (2012) 193-201.

[6] S.E. Riechert, T. Lockley, Spiders as biological control agents, Annual Review of Entomology. 29(1) (1984) 299-320.

[7] K.D. Sunderland et al., Pest control by a community of natural enemies, Acta Jutlandica. 72 (1997) 271-326.

[8] K.D. Sunderland, Mechanisms underlying the effects of spiders on pest populations, J. Arachnol. 27 (1999) 308-316.

[9] A.L. Turnbull, Ecology of the true spiders (Araneomorphae), Annual Review of Entomology. 18 (1973) 305-348.

[10] D.H. Wise, Spiders in ecological web, Cambridge University Press, Cambridge, 1993.

[11] W.S. Bristowe, The Comity of Spiders, Vol. II, Ray Sec. London, 1941. 
[12] D.H.Wise, J.L. Barata, Prey of two syntopic spiders with different web structures, Journal of Arachnology. 11 (1983) 271-281.

[13] T. Watanabe, Effects of web design on the prey capture efficiency of the Uloborid spider Octonoba sybotides under abundant and limited prey conditions, Zool Sci. 18 (2001) 585590.

[14] P. Prokop, D. Gryglakova, Factors affecting the foraging success of the wasp-like spider Argiope bruennichi (Araneae): Role of web design, Biol Bratisl. 60(2) (2005) 165-169.

[15] T.A. Blackledge, J.M. Zevenbergen, Condition-dependent spider web architecture in the western black widow, Latrodectus Hesperus, Animal Behav. 73(5) (2007) 855-864.

[16] B.D. Opell, J.E. Bond, D.A. Warner, The effect of capture spiral composition and orb-web orientation on prey interception, Zoology. 109(4) (2006) 339-345.

[17] K. Nakata, To be or not to be conspicuous: the effects of prey availability and predator risk on spider's web decoration building, Anim Behav.78(5) (2009) 1255-1260.

[18] J.D. Harwood, K.D. Sunderland, W.O.C. Symondson, Web-location by linyphiid spiders: prey-specific aggregation and foraging strategies, Journal of Animal Ecology. 72 (2003) 745756.

[19] T.A. Blackledge, M. Kuntner, I. Agnarsson (eds.), The form and function of spider orb webs: evolution from silk to ecosystems, in: Advances in Insect Physiology, Spider Physiology and Behaviour - Behaviour, Academic Press - Elsevier Science Ltd, London. 2011.

[20] J.D. Harwood, J.J. Obrycki, Web-site selection strategies of linyphiid spiders in alfalfa: implications for biological control, Biocontrol. 52(4) (2007) 451-467.

[21] W.G. Eberhard, Function and phylogeny of spider webs, Annual Review of Ecology and Systematics. 21(1) (1990) 341-372.

[22] L. Bishop, S.R. Connolly, Web orientation, thermoregulation, and prey capture efficiency in a tropical forest spider, Journal of Arachnology. 20 (1992) 173-178.

[23] A.L. Rypstra, Building a better insect trap - an experimental investigation of prey capture in a variety of spider webs, Oecologia. 52 (1982) 31-36.

[24] T.A. Blackledge, C.M. Eliason, Functionally independent components of prey capture are architecturally constrained in spider orb webs, Biology Letters. 3(5) (2007) 456-458.

[25] S. Zschokke et al., Prey-capture strategies in sympatric web-building spiders, Canadian Journal of Zoology-Revue Canadienne De Zoologie. 84 (2006) 964-973.

[26] J.D. Harwood, K.D. Sunderland, W.O.C. Symondson, Living where the food is: web location by linyphiid spiders in relation to prey availability in winter wheat, Journal of Applied Ecology. 38 (2001) 88-99.

[27] J.N. Pruitt et al., Individual- and condition-dependent effects on habitat choice and choosiness, Behavioral Ecology and Sociobiology. 65 (2011) 1987-1995.

[28] M. Nyffeler, K.D. Sunderland, Composition, abundance and pest control potential of spider communities in agroecosystems: a comparison of European and US studies, Agric Ecosyst Environ. 95 (2003) 579-612.

[29] J.D. Harwood, K.D. Sunderland, W.O.C. Symondson, Prey selection by linyphiid spiders: molecular tracking of the effects of alternative prey on rates of aphid consumption in the field, Molecular Ecology.13 (2004) 3549-3560.

[30] E.G. Chapman et al., Molecular evidence for dietary selectivity and pest suppression potential in an epigeal spider community in winter wheat, Biological Control. 65(1) (2013) 72-76. 
[31] T.A. Blackledge, J.W. Wenzel, State-determinate foraging decisions and web architecture in the spider Dictyna volucripes (Araneae Dictynidae), Ethology Ecology and Evolution. 13 (2001) 105-113.

[32] L. Sigsgaard, Early season natural control of the brown planthopper, Nilaparvata lugens: the contribution and interaction of two spider species and a predatory bug, Bulletin of Entomological Research. 97 (2007) 533-544.

[33] A.L. Rypstra et al., Architectural features of agricultural habitats and their impact on the spider inhabitants, Journal of Arachnology. 27 (1999) 371-377.

[34] S.E. Riechert, L. Bishop. Prey control by an assemblage of generalist predators: spiders in garden test system, Ecology. 71(4) (1990) 1441-1450.

[35] A.T. Barrion, J.A. Litsinger, Riceland spiders of south and southeast Asia, CAB International in association with the International Rice Research Institute, Philippines, 1995.

[36] N. Ramalingam, Little encyclopedia of practical Entomology, Super Nova publication, 2003. 